\title{
WEAK AND STRONG POINTS IN THE PERCEPTION OF OWN PREPAREDNESS OF PROSPECTIVE MATH TEACHERS
}

\author{
${ }^{a}$ DOFKOVÁ Radka, ${ }^{\text {b }}$ CHUDÝ Štefan, CZ \\ ${ }^{a}$ Department of Mathematics, Faculty of Education, Palacky University in Olomouc \\ ${ }^{b}$ Institute of Education and Social Studies, Faculty of Education, \\ Palacky University in Olomouc \\ e-mail: ${ }^{a}$ radka.dofkova@upol.cz, ${ }^{b}$ stefan.chudy@upol.cz
}

\begin{abstract}
Research projects in the area of testing the quality of perception of own preparedness of prospective math teachers are taking place in many countries, however, a generally applicable instrument for its testing has not been found. The main goal of this article is to explicitly define the determinants influencing prospective math teachers' preparedness to teach math so that it is possible to use these areas to create a new research tool. Due to the large number of items the Mathematics Teaching SelfEfficacy Scale (Ryang 2010) was used among 121 students of the math teaching program at the Teacher Education Faculty in Olomouc. Based on the results of factor analysis areas of weak and strong points of prospective teachers' preparedness were identified. In order to get a more compact idea statistically significant difference in the respondents' answers was assessed based on their respective study groups. The results proved to be largely consistent.
\end{abstract}




\section{INTRODUCTION}

In recent decades the importance of psycho-didactic aspects of teacher preparation has been increasingly emphasized in scientific circles (Dofková, 2016a, 2016b; Holzberger, Philipp \& Kunter, 2013; Woolfolk-Hoy, Hoy, W. K. \& Davis, 2009). Most of the time teachers subjectively perceive their profession as a mission. In case of teachers this might be influenced by the question of life orientation and mainly their beliefs that develop and change in the course of a teacher's career. In pregraduate preparation it might be difficult to influence beliefs that have already been formed, leading to the question: "What is the level of beliefs of one's own efficacy of prospective elementary school math teachers?"

The most commonly used term in this respect is self-efficacy. Self-efficacy in the education process means the teacher's beliefs how to have a positive effect on the students, how to educate them effectively, how the teacher perceives his/her responsibility for the students' development and performance, how he/she perceives the way he/she deals with problems in class, etc. Self-efficacy is some kind of motivational potential of the teacher, which conditions a lot of energy that the teacher is able to devote to his/her job, how persistent he/she is while dealing with educational situations, and what kind of effort is he/she able to make in order to resolve problems (Bandura,1977; Gavora, 2010).

At a given stage of the relationship between the teacher and his/her self the influence of college environment is especially significant, and that in a whole scale of influence factors - from physical and environmental, social characteristics of study groups, teachers' behavior, to normative requirements set by the study programs (Bandura, 1977). Authors Yavuz et al. (2013) established the level of self-efficacy in prospective teachers based on the faculties where they are studying. Besides other things they found that self-efficacy does not differ based on the respondents' gender, but changes depending on the faculty at which the students are studying. A higher level of self-efficacy was demonstrated by students of technically focused teacher education schools rather than students of normal teacher education schools. A similar study is the work of Gökmen et al. (2011) among the students of biology, where self-efficacy independent of gender was established, but where a difference was found in the assessment of self-efficacy based on the year of study.

Self-efficacy in the preparation of prospective elementary school teachers was tested according to more variables also by Özdemir (2008). His goal was to identify differences in self-efficacy based on gender, type of faculty, study program, type of the high school studied, etc. As opposed to Yavuz et al. (2013) he found that women had a higher perception of self-efficacy for teaching than men, and suggested that there might be two reasons for it. The first is the fact that there are more women in this profession, the second probably greater personality features of women for the teaching profession.

There are studies that agree on the fact that participation of prospective elementary school teachers in subjects of specialized math significantly increases their perception of own efficacy (Huinker \& Madison, 1997). Prospective teachers partaking in these research studies have said that their participation in seminars presenting new trends in teaching math positively influences their self-efficacy, which further influences their fear of math. Mathematics efficacy of a teacher and his/her fear of math have a mutually negative relation - the higher the teacher's self-efficacy, the lower the level of fear of math and vice versa (Swars, 2005). 
Experts dealing with self-efficacy confirm its positive connection to students' performance (Ashton, 1985; Ashton \& Webb, 1986; Klassen \& Chiu, 2011). Some consider high self-efficacy as possibly the most important factor determining a student's success during their studies, determining responsibility for a student's performance characterized by positive attitude to education, better willingness to make changes and being open to them (Bandura, 1997; Guskey, 1982, 1984, 1988; Smylie, 1988; Schunk \& Zimmerman, 2003).

Self-efficacy of prospective teachers influences their motivation and perseverance while achieving goals during their studies. Multiple studies have confirmed that self-efficacy predicates learning or work performance. If a student has high self-efficacy in a particular area of mathematics, then they set higher goals in it since they will not be afraid of failure, or will try to find new strategies in order to achieve their goal, have all the previous strategies failed (Stajkovic \& Luthans, 1998). This also has to do with the question of the right level of self-efficacy. If teacher education students underestimate their abilities, the probability that they will not make adequate effort to reach their goal and give up at the smallest obstacle increases. However, danger also lies in overestimating their abilities. In the short run, overestimating one's abilities may motivate them to better performance, however, if such overestimating is long-term and unrealistic, it does not motivate the student to return to older curriculum in order to fill the gaps in their knowledge. Subsequently, their high self-efficacy does not correspond to their abilities, resulting in inevitable failure (Flammer, 1995).

It is important that self-efficacy be formed during the studies. Australian authors Pendergast et al. (2011) distributed to their master's program students a questionnaire in two stages - at the beginning of their studies and after the teacher training practice. As expected, the students achieved above-average assessment in the first stage of testing. However, the students' assessment at the end of their studies was worse than in the first stage; i.e. their self-efficacy had dropped. This result was confirmed in case of all the programs being assessed, in which the students prepared for teaching in kindergartens, elementary schools and junior high schools. The authors interpret this drop as the result of reality-caused shock that the students experienced after gaining practical experience. Unpleasant experience returned their exaggerated selfassessment from the first stage of the research (Gavora, 2012). Also Pfitzner-Eden (2016) recently stated that teachers in pre-graduate preparation, whose level of selfefficacy increased during their teaching practice, had a smaller tendency to give up the teaching profession as early as during pre-graduate preparation.

In respect to the above facts the main goal of this article is to identify the key areas that teacher education students consider as the weak or strong points of their professional preparedness in order to be able to teach math, and also to establish the differences in assessment among the students of teacher education for elementary schools focused on special education.

\section{METHOD}

In order to measure a teacher's efficacy in teaching math the Mathematics Teaching Efficacy Scale - MTEBI (Enochs, Smith, \& Huinker, 2000) is the one that is used most frequently. Developed in the United States, MTEBI consists of a total of 21 items, out of which 13 are focused on personal mathematics teaching efficacy (PMTE), and eight are focused on mathematics teaching outcome expectancy (MTOE). 
For example Bates, Latham and Kim (2011) used MTEBI in their research study on a sample of students and found that in the pre-graduate stage there is a positive connection between a student's self-efficacy in specialized mathematics and their personal efficacy in terms of teaching it. Thus the performance in math relates to both self-efficacy and a teacher's teaching efficacy. To put it simply - prospective teachers who believe in their abilities to teach will teach effectively. However, Ryang (2010) in his study suggests that MTEBI simply translated without proper modifications may not be generally valid. Based on the analysis of individual items Ryang assembled a larger instrument consisting of 58 items, and that in two versions - one for elementary school teachers and for high school teachers. The objective of the study was achieved by means of the Mathematics Teaching Self-Efficacy Scale - MTSES (Ryang 2010, p. 140). The questionnaire was converted into an electronic format.

\subsection{Research Sample}

A total of 121 students of the Teacher Education Faculty of Palacky University in Olomouc partook in this research; namely the following:

- 84 elementary school teacher program participants

- 28 elementary school and special education teacher program participants

- 3 students of Mathematics focused on education

- 6 students of Teaching mathematics in junior high schools

To analyze inner consistency of scales Cronbach alpha coefficient (.79799) was used. In respect to its value we can confirm adequate inner consistency of the instrument in question.

\subsection{Identified Factors}

Factor analysis as a multi-dimensional statistical method was chosen for the analysis of the structure of mutual dependencies of individual items, its goal being the reduction of the number of items and revealing the structure of interconnectedness among the variables. In our case, the optimum number of factors found was 12 .

The first factor bore the most information of the data set $(11 \%$ proportion of variance), and it was saturated by two types of items. The first group, which was formed by nine items, could be named embarrassment, difficulties or inability of prospective math teachers in terms of their teaching efficacy. These items explored the area of PMTE, were used in singular and were formulated negatively, which was taken into account during their evaluation. In the second area there were items in which the students assessed the extent of their abilities, self-confidence, and high self-efficacy. These items were formulated positively.

Other factors found:

- Total efficacy of prospective teachers to teach math

- Quality of specialized preparation of prospective teachers

- Stagnation or useless effort exerted by the teacher

- Teacher's influence on the students' results in math

- Abilities of prospective teachers to improve the quality of education

- Teacher's work with weak students

- Teacher's development itself 
- Teacher's dispositions for quality teaching

- Teacher's responsibility and students' performance assessment

- Dealing with inspections during lessons

- Effective style of teaching

\section{RESULT}

In respect to the focus of this article the first identified factor, which was saturated by 21 items, is going to be analyzed further. Its basic descriptive characteristics will be mentioned first, then statistically significant difference in answers given by the individual groups.

\subsection{Weak points in the perception of own efficacy of prospective teachers}

All the nine items of the group characterized as embarrassment, inability or worries of the respondents fell into the PMTE area. Verification by Cronbach's Alpha showed that these items were mutually very consistent (.813539). Namely, it concerns the following items:

From Chart 1 it is apparent that $28.10 \%$ of the students have the greatest worries caused by various forms of class inspections (Item 24), despite the fact that in the overall assessment of this item negative answers prevailed (28.93\%). The respondents mentioned the same number of positive answers (i.e. 28.10\%) also in case of the item expressing worries in terms of explaining math terms (Item 58). 21.49\% of the respondents are worried about the necessity to help students understand math terms (Item 19), which is not a big difference compared to the previous two items. Compared to this, only $14.05 \%$ of the respondents are worried about building a positive attitude of their students to math (Item 21).

On the other side of the spectrum, $79.34 \%$ of the respondents disagree with the fact that they might teach math ineffectively (Item 8), i.e. that more than three quarters of them feel prepared to teach mathematics. For $73.55 \%$ of the respondents it will not be difficult to introduce manipulative activities into their math lessons (Item 15), and more than a half of the respondents $(59.50 \%)$ do not think they will not be able to organize and manage mathematical activities during their lessons (Item 6).

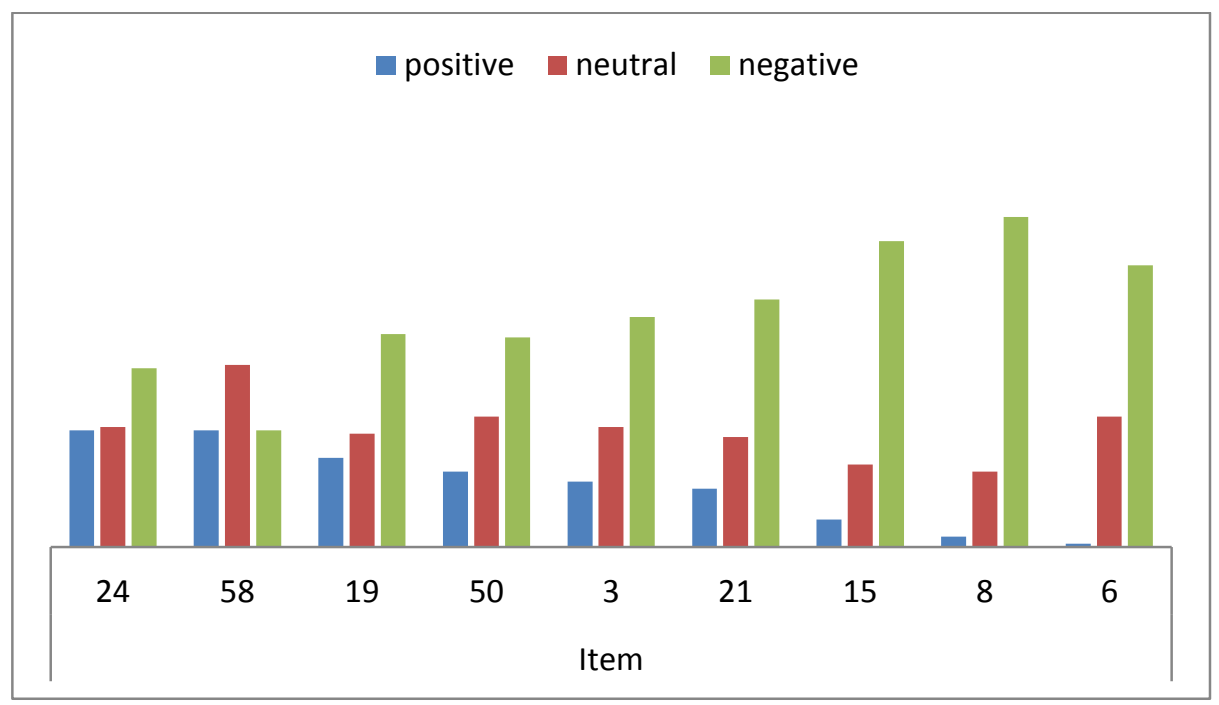

Chart 1: Items assessing embarrassment and difficulties of prospective teachers 


\subsection{Strong points in the perception of own efficacy by prospective teachers}

The second area of the first factor characterized as self-confidence, high selfefficacy or positive assessment of own abilities was formed by twelve items, which were formulated positively (Cronbach's Alpha as high as .874377). In this case those were the following items:

Chart 2 shows that it was found that a total of $89.26 \%$ of the respondents will be willing to answer their students' questions during math lessons (Item 20). Besides that, $74.38 \%$ will be able to provide their students with alternative explanation or examples in case they have difficulties understanding math terms (Item 51). In third place, $70.25 \%$ of the respondents will be able to ensure that their students experience the feeling of success in mathematics (Item 32).

If we focus on the items with the greatest negative assessment, we will find that $14.87 \%$ of the respondents think that they will not be able to answer all their students' questions (Item 23). Almost just as many respondents (13.22\%) think that they will not be adequately appreciated from the side of school management and their students' parents (Item 22). Only $8.26 \%$ of them agree that they will mostly not be able to answer their students' questions regarding mathematics (Item 16).

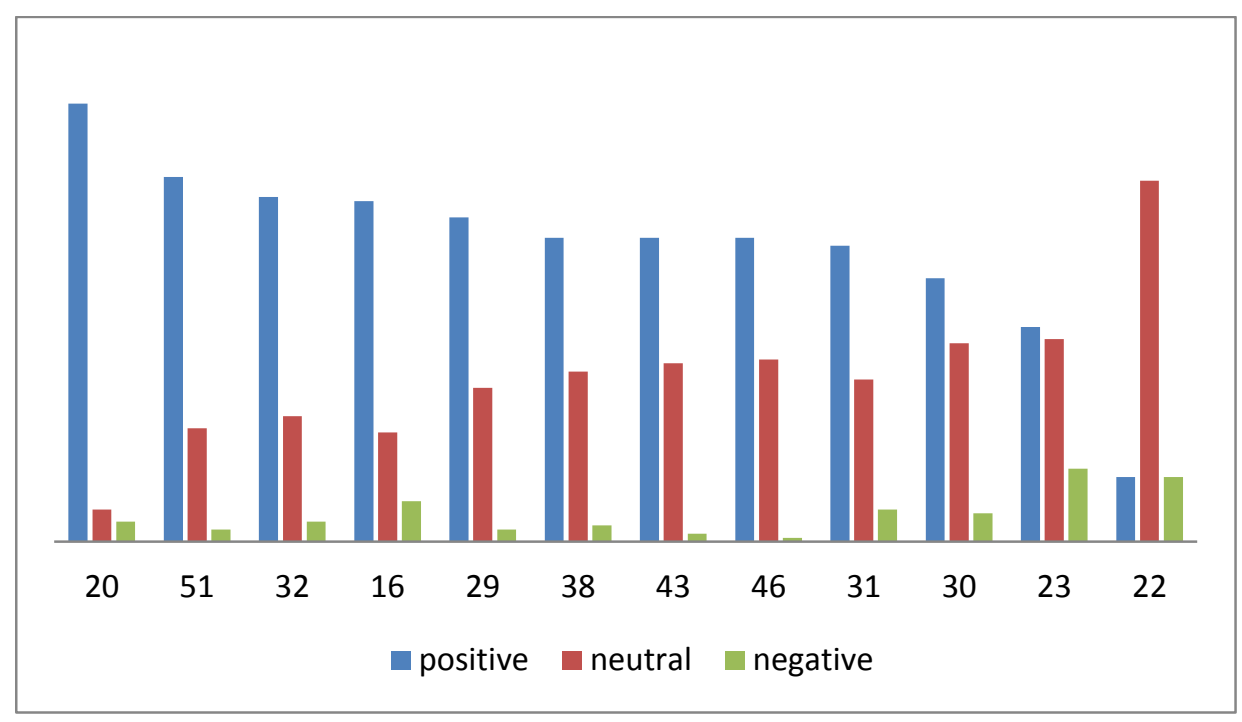

Chart 2: Items assessing abilities and self-efficacy of the respondents

\subsection{Results according to study groups}

From the above mentioned distribution of the research sample it is apparent that a large part of the respondents were students of elementary school teach education there were 69\% elementary school teacher program (ESTP) participants and 23\% elementary school and special education teacher program (ESSETP) participants. In terms of these groups it was absolute collection since all the students of the given program were involved in the research. Thus, we worked with the top sample. Therefore it seemed crucial to find whether there was a statistically significant difference in the assessment of the individual items of the first factor between the two groups.

Data from the research was processed in freely accessible statistical program $R$ (2013). In order to achieve maximum number of objective results it was necessary to reduce each contingency table so that the values were usable for the chosen 
independence tests (i.e. the option definitely yes and yes, and definitely no and no were consolidated in each table). The research assumptions were tested using the chiquadrate and Fisher's combinatorial test; the p-value was calculated at a significance level of .05 and zero and alternative hypotheses were defined:

- $\mathrm{H}_{0}$ : Pre-service teachers' responses do not vary by their study group.

- $\mathrm{H}_{\mathrm{A}}$ : Pre-service teachers' responses vary by their study group.

A statistically significant difference was found only in two items from the first area of items of the factor being explored. The first was Item 3 (Even if I try harder, I won't be able to teach math at the same level as other subjects). Here the p-value was .02638 , which is a value lower than the chosen significance level, and we can rule out zero hypothesis - the respondents' answers in assessment of Item 3 differ based on which study group they were in. In this case the odds ratio was 5.18, thus the ESSETP students assessed the given item five times more negatively than the ESTP students. Thus they are more convinced that they will be able to teach math at the same level as other subjects. The distribution of individual answers within the groups can be seen in Chart 3.

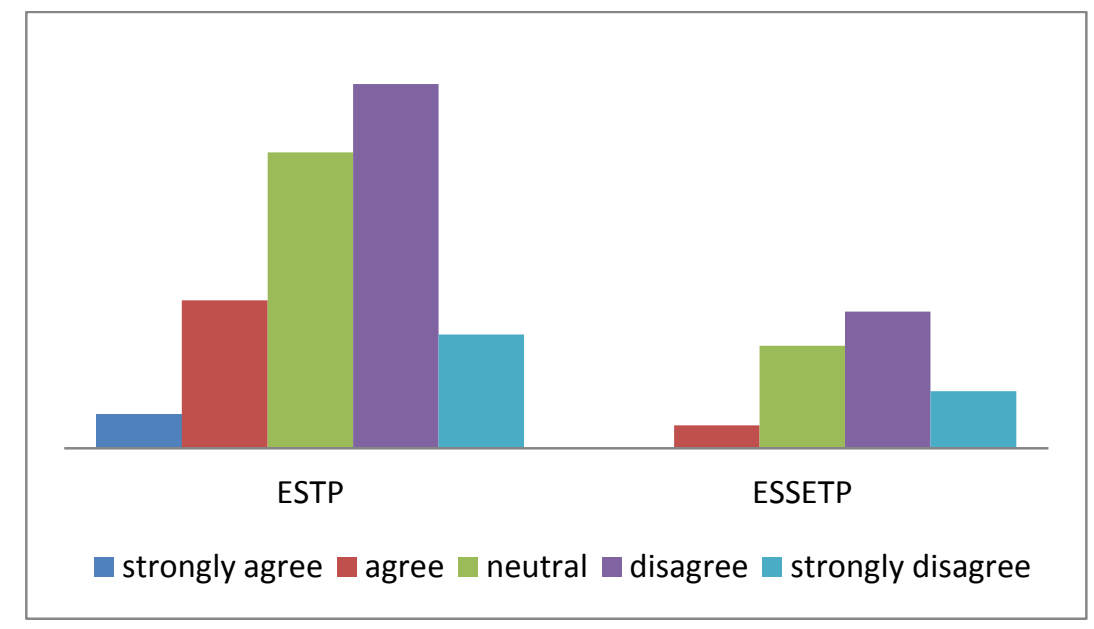

Chart 3: The ability to teach math at the same level as other subjects

The second item in which a statistically significant difference was found was Item 50 (I will have difficulties adapting my math lessons to the needs of individual students). Here the p-value was calculated to be .01666 , which is again a lower value than the chosen significance level, and we can rule out zero hypothesis. In respect to the calculated odds ratio of 8.766 we can say that the chance to get a negative answer in the ESSETP group was almost 9 times higher than in the ESTP group, which means that the ESTP students have bigger worries whether they will be able to adapt their own teaching to the needs of the students. The distribution of answers is shown in Chart 4. 


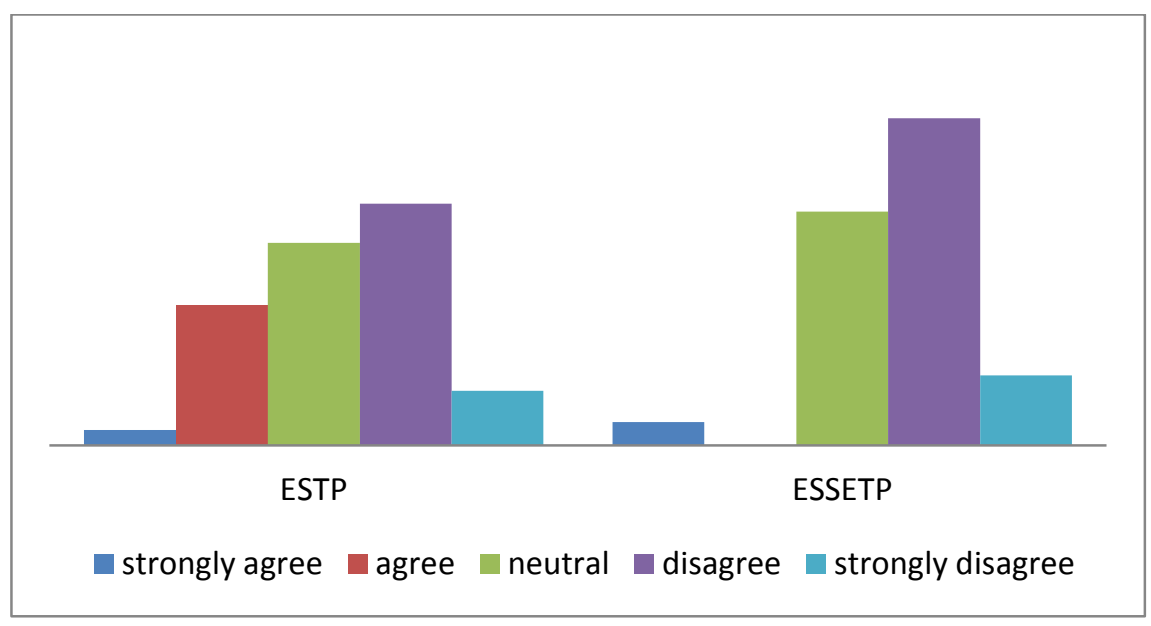

Chart 4: Adaptation of teaching math to the needs of the students

\section{DISCUSSION}

We can sum up that in those items, where the respondents were supposed to assess the amount of own worries, there was almost always a negative answer through which they expressed their preparedness to teach math. The only area where the answers were relatively balanced was indecisiveness in terms of own preparedness to clearly explain certain math topics to students. Since students entering a teacher education program have a significantly negative attitude to mathematics as such, it is very difficult for them to didactically interpret individual math topics.

Positive assessment prevailed in case of most items also in the area of assessment of own strong points. Understandable embarrassment was felt by the respondents only in case of the item assessing their preparedness to answer all their students' questions. Based on the fact that at the time of testing the respondents were yet to do consistent teacher education practice, they had no experience communicating with students in general, let alone with specific communication in math lessons.

In general, it is clear from the above mentioned results that teacher education students have a low level of self-efficacy, and namely in those areas that concern the formation of a student's personality in math lessons they require more anchored scientific knowledge or are immediately connected to students' experience with teacher education. These conclusions are more or less valid across the study groups. In respect to the character of the studies only ESSETP students felt more prepared to adapt their teaching to individual needs of their students.

Even if the above mentioned instrument is directly designed for prospective elementary school teachers, we feel that especially in respect to the extent of the items it does not necessarily have to be generally valid. This is one of the reasons why we are currently creating a new instrument that would better correspond to the conditions of the Czech education system as the target group. 


\section{REFERENCES}

Ashton, P.T., \& Webb, R. B. (1986). Making a difference: teachers' sense of efficacy and student achievement. New York: Longman.

Bandura, A. (1977). Self-efficacy: Toward a unifying theory of behavior change. Psychological Review, 84, 191-215.

Bandura, A. (1997). Self-efficacy: The exercise of control. New York: Freeman.

Bates, A. B., Latham, N., \& Kim, J. A. (2011). Linking preservice teachers' mathematics self-efficacy and mathematics teaching efficacy to their mathematical performance. School Science and Mathematics, 111(7), 325-333.

Dofková, R. (2016a). Beliefs of prospective mathematics teachers about their preparedness for teaching mathematic [on-line]. In ICLEL2016 Proceedings (pp. 488-493). [cit. 2017-06-05]. Available from https://www.iclel.com/iclel16-publications.

Dofková, R. (2016b). Přesvědčení o připravenosti budoucích učitelů matematiky jako didaktická výzva primárního vzdělávání. Olomouc: VUP.

Flammer, A. (1995). Developmental analysis of control beliefs. In: A. Bandura (Eds.), Self-efficacy in changing societies (pp. 69-113). Cambridge: Cambridge University Press.

Gavora, P. (2010). Slovak pre-service teacher self-efficacy: theretical and research consideration. The New Educational Review, 21(2), 17-23.

Gavora, P. (2012). Skúsenosti so zist'ovaním self-efficacy učitela pomocou dotazníka OSTEN. In V. Ježková (Ed.), Kvalita ve vzdělávání (pp. 9-11). Praha: Pedagogická fakulta UK.

Gökmen, A., et al. (2011). An investigation into candidate biology teachers selfefficacy beliefs related to the teaching process. Social and Behavioral Sciences, $15,2559-2563$.

Guskey, T. (1982). Differences in teachers' perceptions of personal control of positive versus negative student learning outcomes. Contemporary Educational Psychology, 7, 70-80.

Guskey, T. (1984). The influence of change in instructional effectiveness upon the affective characteristics of teachers. American Educational Research Journal, $21,245-259$.

Guskey, T. (1988). Teacher efficacy, self-concept,and attitudes toward the implementation of instructional innovation. Teaching and Teacher Education, 4(1), 63-69.

Holzberger, D., Philipp, A., \& Kunter, M. (2013). How teachers' self-efficacy is related to instructional quality: A longitudinal analysis. Journal of Educational Psychology, 105(3), 774-786.

Huinker, D., \& Madison, S. K. (1997). Preparing efficacious elementary teachers in science and mathematics: The influence of methods courses. Journal of Science Teacher Education, 8(2), 107-126. 
Klassen, R. M., \& Chiu, M. M. (2010). Effects on teachers' self-efficacy and job satisfaction: Teacher gender, years of experience, and job stress. Journal of Educational Psychology, 102, 741-756.

Özdemir, S. M. (2008). An investigation of prospective primary teachers'self-efficacy beliefs regarding teaching process in terms of certain variables. Educational Administration: Theory and Practice, 54, 277-306.

Pendergast, D., Garvis, S., \& Keogh, J. (2011). Pre-service student-teacher selfefficacy beliefs: An insight into the making of teachers. Australian Journal of Teacher Education, 36(12), 4.

Pfitzner-Eden, F. (2016). I feel less confident so I quit? Do true changes in teacher self-efficacy predict changes in preservice teachers' intention to quit their teaching degree? Teaching and Teacher Education, 55, 240-254.

Ryang, D. (2010). The development of the mathematics teaching self-efficacy scales for korean elementary and secondary preservice teachers. Unpublished Doctoral Dissertation, University of Alabama. Alabama, USA. 